\title{
Acromegaly and gigantism in the medical literature. Case descriptions in the era before and the early years after the initial publication of Pierre Marie (1886)
}

\author{
Wouter W. de Herder
}

Published online: 6 August 2008

(c) The Author(s) 2008. This article is published with open access at Springerlink.com

\begin{abstract}
In 1886 Pierre Marie used the term "acromegaly" for the first time and gave a full description of the characteristic clinical picture. However several others had already given clear clinical descriptions before him and sometimes had given the disease other names. After 1886, it gradually became clear that pituitary enlargement (caused by a pituitary adenoma) was the cause and not the consequence of acromegaly, as initially thought. Pituitary adenomas could be found in the great majority of cases. It also became clear that acromegaly and gigantism were the same disease but occurring at different stages of life and not different diseases as initially thought. At the end of the 19th and beginning of the 20th century most information was derived from case descriptions and post-mortem examinations of patients with acromegaly or (famous) patients with gigantism. The stage was set for further research into the pathogenesis, diagnosis and therapy of acromegaly and gigantism.
\end{abstract}

Keywords Acromegaly · Gigantism · History · Pituitary · Growth hormone

In 1886 Pierre Marie (1853 Paris (France) - 1940 Paris (France)) used the term "acromegaly" for the first time and gave a full description of the characteristic clinical picture: "Il existe une affection caractérisée surtout par une hypertrophie des pieds, des mains et du visage, que nous proposons d'appeler acromégalie, c'est-à-dire hypertrophie

W. W. de Herder $(\square)$

Department of Internal Medicine, Sector of Endocrinology,

Erasmus MC, 's Gravendijkwal 230, 3015 CE Rotterdam,

The Netherlands

e-mail: w.w.deherder@erasmusmc.nl des extrémités (non pas qu'en réalité, les extrémités soient seules atteintes pendant toute la durée de la maladie, mais parce que leur augmention de volume est un phénomène initial et constitue le trait le plus caractéristique de cette affection). L'acromégalie est tout a fait distincte du myxœdème et de la maladie de Paget (ostéite déformante), ainsi que de la leontiasis ossea de Virchow" [1] [A condition characterized by hypertrophy of the hands, feet and the face exists which we propose to be called «acromegaly» which means hypertrophy of the extremities. In reality the extremities are swollen during the disease course and their increase in volume is the most characteristic feature of this disease. Acromegaly is different from myxedema, Paget's disease or leontiasis ossea of Virchow.] Marie, however, was not the first physician to give a clear description of the clinical picture of acromegaly. Others had done this years before him, like (possibly) the Dutch surgeon and active opponent of superstition and witch-burning, Johannes Wier (1515-1588) already in 1567 [2], or Saucerotte in 1772 [3, 4]. Other physicians had also given the disease different names including Alibert in 1822 calling it "Géant scrofuleux" [5], Verga in 1864 calling it "Prosopo-ectasia" [6] and Lombroso in 1869 calling it "Macrosomia" [7, 8]. A total of more than 20 physicians had already published on disorders, which later could be reclassified as cases of acromegaly (Table 1). In 1886, Marie was not yet aware of any pituitary pathology in patients with acromegaly. In the following years he and his co-workers J. D. Souza-Leite and G. Marinesco significantly contributed to further knowledge on the clinical features and pathology of acromegaly by publishing many important papers in this field [9-19]. Several authors had reported on the coexistence of sellar, or pituitary enlargement in patients with acromegaly, but it was not clear whether this was the cause or the consequence of the disease. It was also debated whether 
Table 1 Description of acromegaly in the medical literature up to 1886

\begin{tabular}{|c|c|c|}
\hline Author & Reference Number & Year of Publication \\
\hline Weyer & {$[2]$} & 1567 \\
\hline Saucerotte & [3] & 1772 \\
\hline Noel & {$[42]$} & 1779 \\
\hline Gall & [91] & 1810 \\
\hline Alibert & {$[5]$} & 1822 \\
\hline Verga & [6] & 1864 \\
\hline Lombroso & [7] & 1869 \\
\hline Magendie & {$[92]$} & 1839 \\
\hline Chalk & [93] & 1857 \\
\hline Friedreich & [94] & 1868 \\
\hline Henrot $^{\mathrm{a}}$ & {$[95,96]$} & 1877 \\
\hline Brigidi $^{b}$ & {$[97,98]$} & 1877 \\
\hline Taruffi & {$[99,100]$} & 1877 \\
\hline Cunningham & {$[101]$} & 1879 \\
\hline Ellinwood & {$[102]$} & 1883 \\
\hline Fritsche and Klebs & [29] & 1884 \\
\hline Hadden and Balance & {$[103,104]$} & 1885 \\
\hline Wadsworth & [105] & 1885 \\
\hline Wilks & {$[42]$} & 1886 \\
\hline Motais & [42] & 1886 \\
\hline
\end{tabular}

${ }^{a}$ Describes the postmortem finding of a tumor at the base of the brain in the midline-pituitary area

${ }^{\mathrm{b}}$ Life history and postmortem report of the famous Italian actor Ghirlenzoni

acromegaly was a result of hypo- or hyperfunction of the pituitary. In 1864 Verga had already described sellar enlargement in a patient with acromegaly. Minkowski in 1887 reported that pituitary enlargement was found in all postmortem studies of patients with acromegaly [20]. Massolongo in 1892 could correlate acromegaly to increased pituitary function by demonstrating that a pituitary tumor from a patient with acromegaly contained specific granulated cells [21]. Eventually, the relationship between a pituitary hyperfunction-hypertrophy, or a hyperfunctioning pituitary tumor and acromegaly was clearly established and confirmed at the end of the 19th century by many authors [22-27]. Initially, it was also believed that acromegaly and gigantism were two totally different diseases. Marie [11-17], his intern Souza-Leite [9] and Guinon [28] were convinced that acromegaly and gigantism were two entirely different disorders. Gigantism was considered as an exaggerated variant of normal development, whereas acromegaly was considered as a pathological condition. However, Fritsche and Klebs in 1884 [29], supported by the work of Langer (1872) [30], concluded that in contrast to gigantism, which they considered as a congenital disorder, acromegaly was an acquired variety of gigantism occurring at a later age when growth is completed. In 1894 Sternberg concluded that there were many similarities between acromegaly and gigantism [31]. However, in 1897 he changed his view and agreed with Marie and others that both disorders were different [32]. Cunningham in 1891—studying the skeleton of the Irish giant Cornelius Magrath (1736 Silvermines (Ireland)-1760, Dublin (Ireland); the skeleton was the possession of Trinity college, Dublin) [33-35], Dana in 1893 [36] and Hutchinson in 1893 [37-40]—describing the case report and postmortem studies of the French giantess Emma Aline Batallaid (also known as Lady Aama, 18771895) - also pointed to the connection between acromegaly and gigantism. It gradually became clear that both disorders had the same pathogenetic mechanism, but differed with regard to the age of onset. Gigantism would occur much earlier in life, when the skeleton still had the potency to grow, a developmental phase we now call pre-pubertal [41, 42].

The famous surgeon John Hunter could have been the first to describe pituitary enlargement in gigantism/acromegaly, if only he would have opened the skull of the giant Charles Byrne of Littlebridge (Ireland) (later also known as O'Brien) whose remains came into Hunter's possession after the death of the giant in London (UK) in June 1783. But, as stated by the famous neurosurgeon Harvey Cushing, "his passion as a collector exceeded his thirst for knowledge" [43]. In 1909, Cushing together with the curator of the John Hunter museum in London (UK) opened the skull of the Irish giant and demonstrated that the sella turcica was enlarged measuring $21 \times 24 \mathrm{~mm}$ and being $11 \mathrm{~mm}$ deep [43-46].

So, finally in the early years of the 20th century the cause of acromegaly and gigantism had become known.

An abnormal stature, or phenotype, like being too tall attracted the attention of the community and also doctors. Therefore, many case reports on generally famous giant acromegalic patients have been subsequently published by experts in the field.

Besides from being an expert pathologist, Professor Rudolf Ludwig Karl Virchow (1821, Schievelbein (Prussia)-1902, Berlin (Germany)) also showed particular interests in anthropology. He wrote two papers on famous patients with gigantism; Lewis Wilkins and Franz Winkelmeier [47-49].

Lewis Wilkins (1874, Minnesota (USA)-1902, Chicago, (USA)) (Fig. 1) had a reported height which varied between $2.26 \mathrm{~m}$. (7 ft. $5 \mathrm{in}$.) and $2.535 \mathrm{~m}$. ( $8 \mathrm{ft}$. $3 \frac{1}{2}$ in.). An impressive feature was his asymmetrical left facial hypertrophy, which was initially diagnosed as "leontiasis ossea" $[36,48,50]$. Months before his death he first suddenly lost the vision in his left eye and suffered from excruciating headaches. Later he became blind in his right eye. He also experienced deafness in the left ear and 


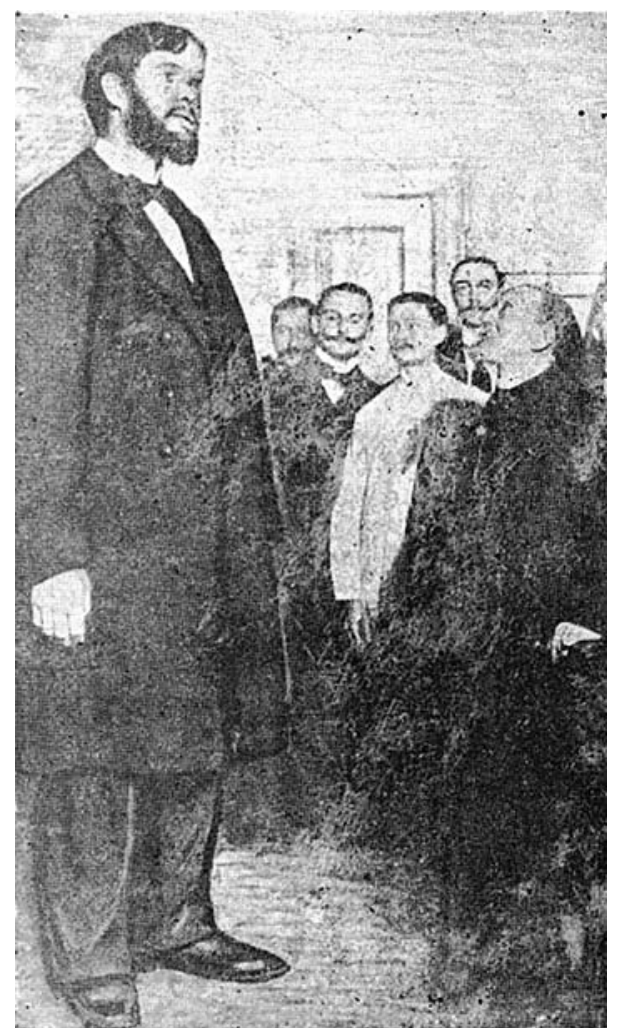

Fig. 1 Lewis Wilkins (1874, Minnesota (USA)—1902, Chicago, (USA)) together with Professor Rudolf Ludwig Karl Virchow (1821, Schievelbein (Preussen)-1902, Berlin (Germany) and his team in 1900 in Berlin (Germany). Collection W.W. de Herder

loss of feeling on the left side of the face and the left part of his tongue. He died from ulcerative colitis accompanied by bronchopneumonia. He was autopsied by Drs. P. Bassoe, L. Loeb, and Prof. Hektoen at the Presbyterian Hospital in Chicago (USA). A sarcomatous tumor with extension in the pituitary area and diffuse left sided hyperostosis was found. The pituitary seemed normal. The thyroid was multinodular and enlarged [51, 52].

Franz Winkelmeier (1860, Lengau (Austria)—1887, Lengau (Austria)) started growing rapidly at puberty and

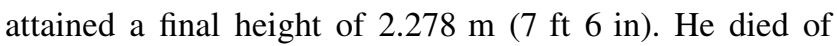
tuberculosis [47, 53].

Fedor Machnow (1880, Kustiaki/Witebsk (Russia)1920, USA)) (Fig. 2) started to grow rapidly from the age of 4 years. Drs. Von Luschan and Lissauer (Berlin, Germany) reported his anthropometrics in 1903 when he was 22 years old [54]. His height was $2.38 \mathrm{~m}$ ( $7 \mathrm{ft} 93 / 4 \mathrm{in}$ ), his feet were $149 \mathrm{~mm}\left(5^{3 / 4} \mathrm{in}\right)$ wide and $370 \mathrm{~mm}\left(1 \mathrm{ft} 2 \frac{1}{2}\right.$ in) long. He was described as being of normal intelligence. In 1904 , at the age of 23 , Dr. M. Zondek was able to repeat the anthropometry [55]. In this paper a height of $2.36 \mathrm{~m}$ (7 ft 9 in) is reported. A skull radiograph was also made, but a description of the sella turcica is, regretfully, lacking. However, the skull radiograph did show extensive

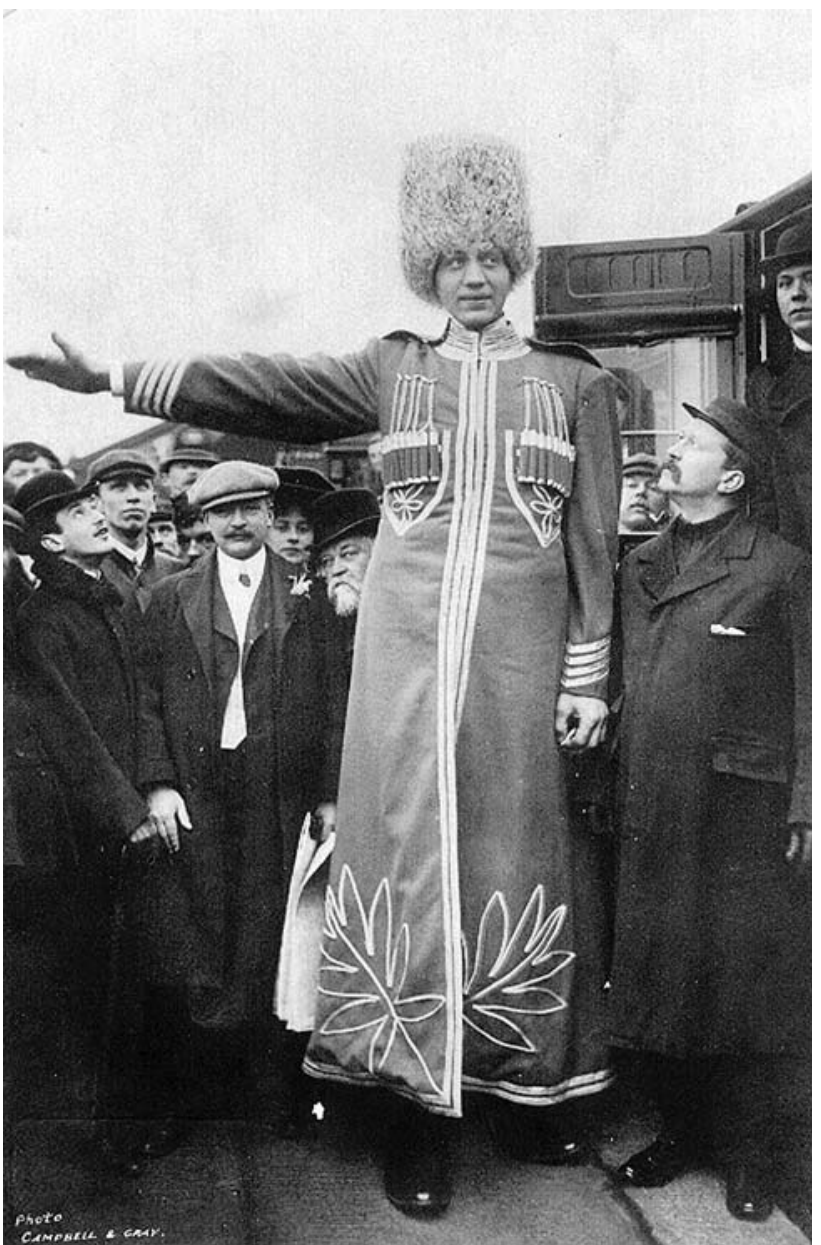

Fig. 2 Fedor Machnow (1880, Kustiaki/Witebsk (Russia)-1920, (USA)) photographed at the "London Hippodrome, London (UK) in 1905. Collection W.W. de Herder

pneumatisation of the frontal sinuses. Interestingly, the publication describes a remarkable increase in pulse frequency from the supine position (68 beats per minuteb.p.m.) to the erect position (108 b.p.m.) suggestive of orthostasis. A radiograph of the hand showed complete ossification, suggesting that Machnow had stopped growing. He died of tuberculosis.

A post-mortem examination of Battista Ugo (in French: Baptiste Hugo; 1876, Vinadio (Italy)—1916, New York (USA)) was performed and published by Symmers in 1917 [56]. He was one of the Hugo brothers, also known in France as "les Geants des Alpes" (Fig. 3). Baptiste attained a height of $2.30 \mathrm{~m}$. (7 ft. $7 \mathrm{in}$.) and weighed $201 \mathrm{~kg}$. (443 lbs.). His brother Paolo Antonio Ugo (in French: Antoine Hugo; 1887, Vinadio (Italy)-1914, Mairsons-Alfort (France)) had a final height of $2.25 \mathrm{~m}$. (7 ft. $5 \mathrm{in}$.) and he weighed $150 \mathrm{~kg}$. (331 lbs.). They had 3 brothers and 2 sisters of normal length [57]. Baptiste Hugo, while traveling the USA working for the Barnum \& Bailey circus was admitted to the William Parker hospital in New 


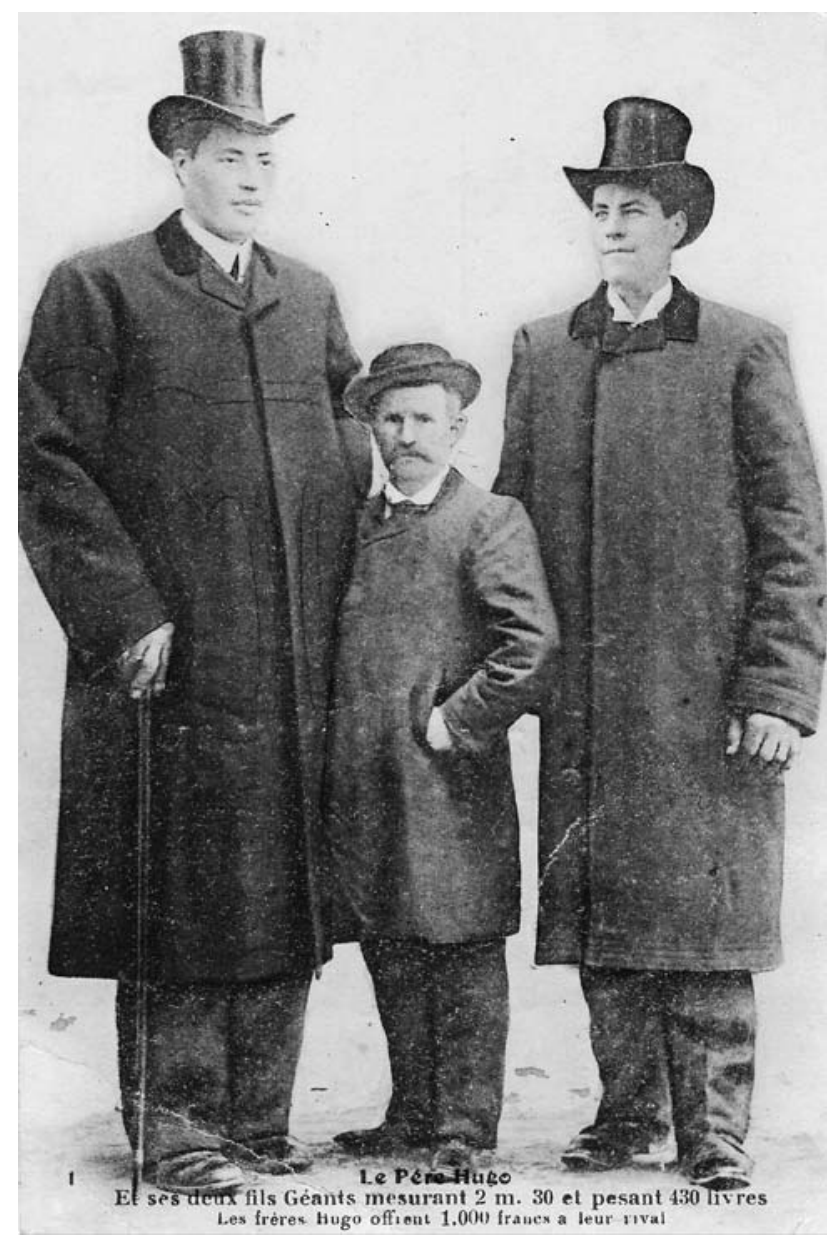

Fig. 3 Familial acromegaly. Battista Ugo (Baptiste Hugo; 1876, Vinadio (Italy) - 1916, New York (USA)) - the tallest person in the picture), Paolo Antonio Ugo (Antoine Hugo; 1887, Vinadio (Italy)_ 1914, Mairsons-Alfort (France)) and their father (the smallest person in the picture). Collection W.W. de Herder

York on 22 April 1916 with the diagnosis of diphtheria and died the next day (23 April 1916). In the post-mortem report his height is reported as $2.59 \mathrm{~m}$. (8 ft. $10 \mathrm{in}$.), which is much taller than his reported height when still alive. The report further describes testicular atrophy, micropenis and scanty pubic, facial and axillary hair as features of hypogonadism. Osteoporosis of the skull bones was found. Clear acromegalic features were described including: frontal bossing, prognathism and the large size of both hands as well as most internal organs. A pituitary adenoma measuring $50 \times 25 \times 23 \mathrm{~mm} . \quad(2 \times 1 \times 0.9$ in. $)$ and weighing 5.94 gram with suprasellar expansion compressing both optic nerves, and also left parasellar and retrosellar expansion was found. Further findings were: a so-called "cystic adenoma" of the thyroid and atrophy of both adrenals [56]. The Hugo brothers are presumably the first patients with familial acromegaly to be described in the literature.
Frederic John Kempster (1889, Bayswater, London (UK) - 1918, Blackburn (UK))-was also known as "the Blackburn Giant" or "The Gentle Essex Giant" or "Frederick the Great" (Fig. 4) [58]. At the onset of the age of 15, he experienced rather severe headaches and started growing rapidly. At his death at the age of 29 he was $2.56 \mathrm{~m}$. (8 ft. $4 \frac{1}{2} \mathrm{in}$.) and weighed $171.5 \mathrm{~kg}$. (378 lbs.) and wore size 22 shoes (410 mm., 16 inches long). Anthropometrics and his case history were taken by Dr. Gigon (Basle, Switzerland) in $1915[59,60]$. He was of normal intelligence. He had typical acromegalic features including: prognathism, large hands, a big nose and a large tongue. The right foot was $34 \mathrm{~cm} \mathrm{(1} \mathrm{ft.}$ $1 \frac{1}{2}$ in.) and the left foot size was $32,5 \mathrm{~cm}$ ( $1 \mathrm{ft} .1 \mathrm{in}$.) in length. He had a kyphoscoliosis. He had a deep voice although he used to be a tenor until the age of 18 . There were signs of hypogonadism as: the absence of a beard and a moustache as well as the absence of axillary hair or chest hair. There was scanty pubic hair. Testis size was normal for

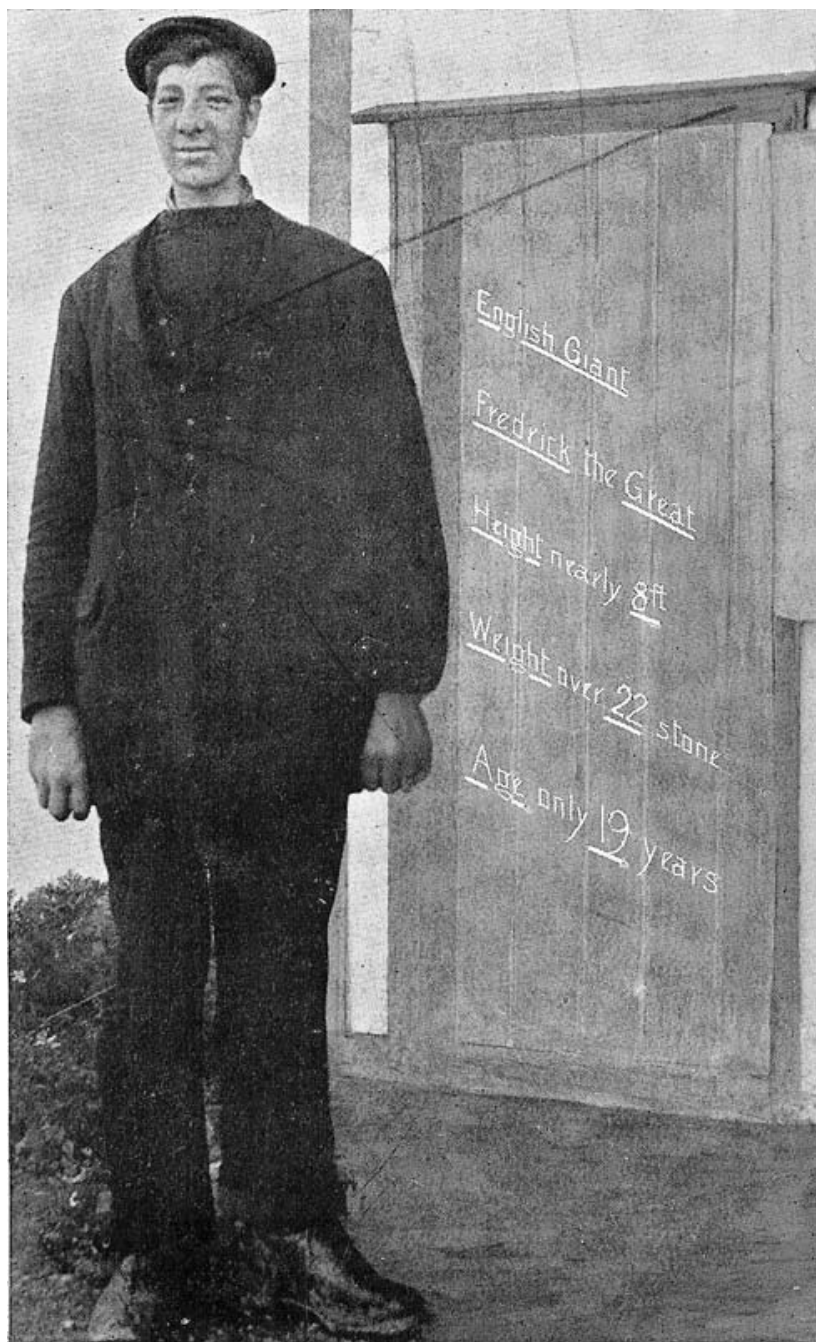

Fig. 4 Frederic John Kempster (1889, Bayswater, London (UK) 1918, Blackburn (UK)). Collection W.W. de Herder 
a normal-sized man. The left leg was shorter than the right leg. The muscles were weak. A sellar radiograph showed an enlarged sella turcica with a diameter of $28 \mathrm{~mm}\left(1 \frac{1}{4} \mathrm{in}\right)$. A hand radiograph showed that the epiphysial plates had not yet fully closed. Furthermore there was marked osteoporosis $[59,60]$. In 1910 he traveled to Germany, to work in the vaudeville where he was called "Teddy Bobs". At the outbreak of the First World War he was interned as a "prisoner of war" by the Germans in 1914. He prompt fell ill and was hospitalized until his release in 1916. Back in England, his health remained poor and in 1918 he fell ill with pneumonia as a result of the influenza epidemic and died [58].

The Swiss anthropologist Schlaginhaufen examined the Dutch giant Albert Johan Kramer (1897, Amsterdam, The Netherlands), also known as "Lofty" (UK) and "Jan van Albert" (USA and Europe) in July 1923 in Albisgütli (Switzerland) (Fig. 5) [61]. Kramer's final height was $2.42 \mathrm{~m}$. (8 ft.), although his maximum reported height was $2.69 \mathrm{~m}$. (8 ft. 93/4 in.) [61, 62]. He weighed $165 \mathrm{~kg}$ (364 lbs). Schlaginhaufen was able to register 40 anthropometric data except his overall height, because of "Geschäftsgeheimnis" (professional secrecy), reported by Kramer himself as $2.54 \mathrm{~m}$.(8 ft. $4 \mathrm{in}$.). He also was convinced that Kramer did not suffer from acromegaly [61, 62].

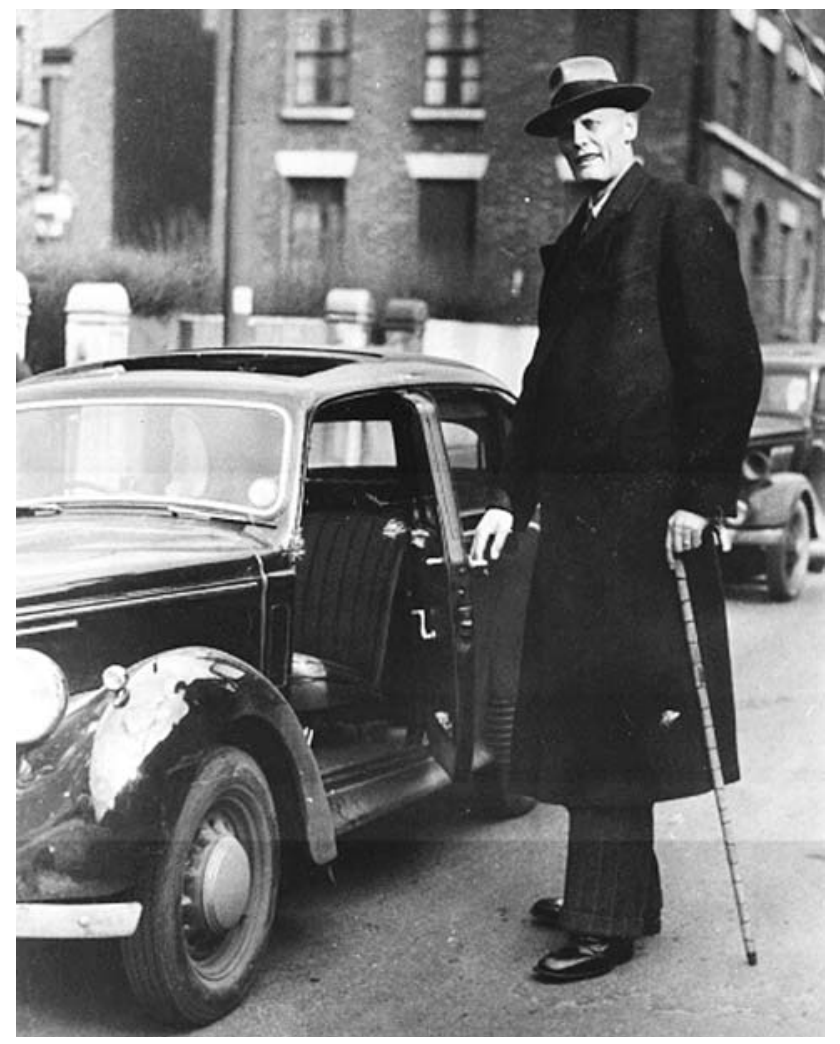

Fig. 5 Albert Johan Kramer (1897, Amsterdam, The Netherlands). Collection W.W. de Herder
Dr. Charles D. Humberd of Barnard, Mo. wrote 2 reports on 2 famous patients with gigantism. Henri Mullins (1915, Atlanta (Georgia, USA) -1972, Los Angeles (USA)) was described by Humberd as an acrobatic, alert, intelligent, well-read, affable, friendly, thoroughly qualified businessman and a "good trouper". He underwent one single course of pituitary radiotherapy. He did not suffer from visual impairment. He had a normal libido and normal testes. There were no headaches. There were multiple (scars of) furuncles and slight acne. A complete anthropometric picture was given by Humberd in his publication in 1938: His height then was $2.305 \mathrm{~m}$. (7 ft. $63 / 4 \mathrm{in}$.), the circumference of his ring finger (dig IV) was $8 \mathrm{~cm}$. ( $3 \frac{1 / 4}{4}$ in.), the length of the feet was $39 \mathrm{~cm}$. (1 ft. $3^{1 / 2} \mathrm{in}$ ) [63]. He worked as a vaudeville and movie artist. His theatre name was "Henri Hite". Among the movies he acted in were: "The Side Show Mystery" (1932) and "Monster a-Go Go" (1965).

Robert Pershing Wadlow, (1918, Alton, Illinois (USA) - 1940, Manistee, Michigan (USA)) is still considered as the tallest man on earth from the year 1937 onwards (Fig. 6). His final height was $2.72 \mathrm{~m}\left(8^{\prime} 11.1^{\prime \prime}\right)$ [64]. His

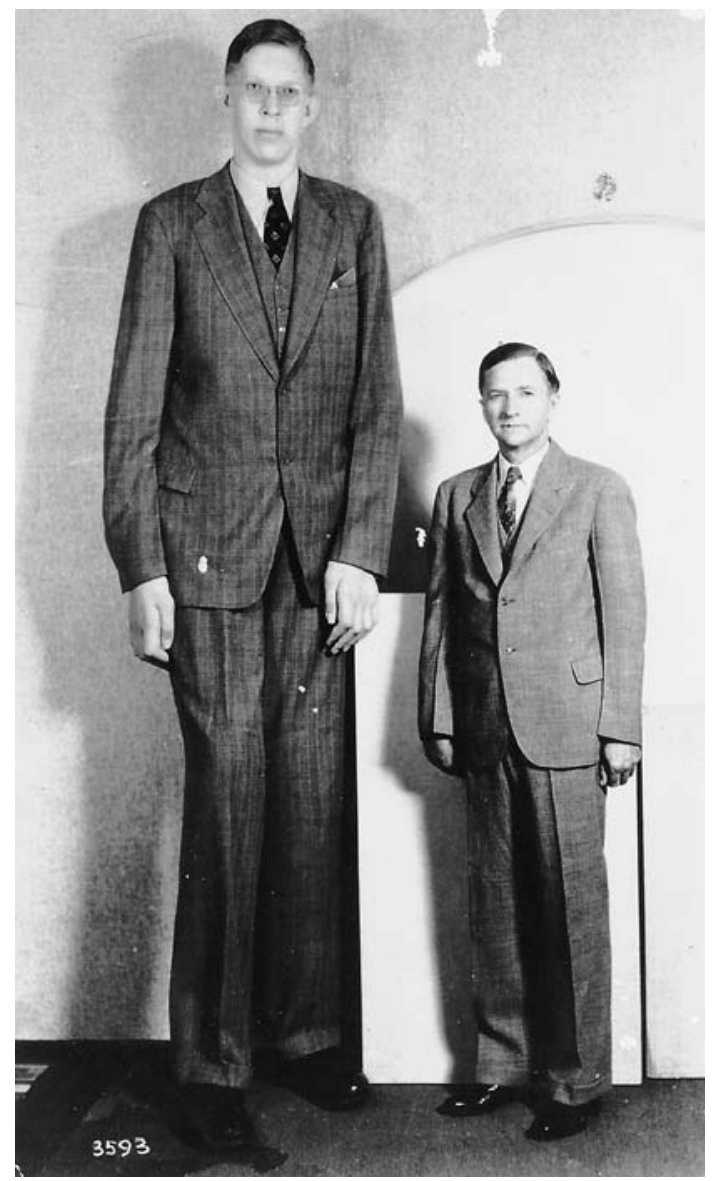

Fig. 6 Robert Pershing Wadlow, (1918, Alton, Illinois (USA)1940, Manistee, Michigan (USA)) and his father. Collection W.W. de Herder 
case was already reported by Behrens in 1932 [65]. At the time of his death he weighed $222 \mathrm{~kg}$ (490 pounds). In June 1936 Wadlow was visited at his home by Humberd. The story goes that Humberd more or less imposed himself on the Wadlow family and after a short visit left disgruntled the house when Wadlow refused to cooperate and refused a medical examination [66]. Successively, Humberd published a paper in the JAMA describing Wadlow as a "pre-acromegalic giant" [67]. The Wadlow family was especially mortified and grieved by the following phrase in the Humberd paper: "His expression is surly and indifferent, and he is definitely inattentive, apathetic and disinterested, unfriendly and antagonistic. His frequently voiced plaints are: "It's not my fault that I am this way", and "I didn't have anything to do with me getting to be like this". His soured attitude has embittered him very much, and he is introverted and morose, though the newspaper stories, usually quoting his school teachers, say that he is very alert and intelligent. His defective attention and slow responses hold for all sensory stimuli, both familiar and unexpected, but he does manifest a vapid interest in seeing any memoranda made by a questioner". Humberd further doubted Wadlow's intellectual capacities [67]. The publication was considered by the Wadlow family as insulting and humiliating. They felt violated as, they put is, they had not realized that "any person in the name of science had the right to come into a home, make whatever cursory observations he could and then broadcast these observations to the world" [66]. The Wadlows filed suit against Humberd and the American Medical Association. Despite the fact that many witnesses verified that the description of Wadlow, as published, was a distortion of his general condition, they lost the trial on a technicality. The judge ruled that the description was a case study and that the portrait of Robert might have been accurate on the day of his examination [66]. The action against the American Medical Association never came to trial. After three years of maneuvers it was dismissed after Robert died 15 July 1940 in Manistee, Michigan as a result of an infected ulcer caused by pressure of a brace which he had to wear because of peroneal nerve paralysis (drop foot). He was buried in his hometown Alton, Illinois (USA).

A case report of John Aasen, (1890, Hennepin County (Minnesota, USA) -1938, Mendocino (California, USA)) at the age of 46 years was published in 1937 by Gray [68]. His growth and weight history are also given. At age 46 his length was $2.13-2.33 \mathrm{~m}$. (7 ft. 0-9 in.) and his weight was $129.3 \mathrm{~kg}(285 \mathrm{lbs})$. The report describes a number of examinations and tests which were done during a hospital admission because of foot ulcers. The medical history revealed that he had frontal headaches since the age of 28 . There was progressive loss of the bitemporal visual fields from the age of 31 till age of 41 after which there was stabilization but no improvement. His IQ was low and his memory was poor. Libido was absent. He is described as "obviously acromegalic" and "a veritable giant". The report further mentions scanty body hair and epilepsy since the age of 41. Ophthalmologic examination revealed bitemporal hemianopsia and optic atrophy. The testes were small and soft with a length of about $2 \mathrm{~cm}$. Glucose intolerance and secondary hypothyroidism (low basal metabolic rate) were diagnosed. A skull X-ray showed hyperostosis. The sella turcica was enlarged with a diameter of $2 \mathrm{~cm}$ but there was no erosion of the bone. The treatment consisted of a hypercaloric diet, iron, liver and stomach concentrate, adrenal cortex extract and thyroid extract. It was decided to postpone pituitary surgery "until the general vigor could be improved". Also pituitary radiotherapy was not given because of "the probability that the patient would leave town (San Francisco) shortly so that follow-up would be inadequate" [68]. He died one year later. John Aasen became famous because of his part in the Harold Lloyd movie classic "Why Worry?" (1923). $\mathrm{He}$ acted in several other films. He was also known as the "The Minneapolis Giant", or the "Norwegian Giant". He had willed his body to Dr. Humberd for research purposes and dissection. The actual location of his skeleton after the death of Dr. Humberd is yet unknown.

Jacob Ehrlich (Jack Earle) (1906, Denver (Colorado, USA)-1952 El Paso (Texas, USA)) developed normally until the age of 8 . From then on he grew rapidly until the age of 16 (Fig. 7). His final height was $2.32 \mathrm{~m}$. (7 ft $7.5 \mathrm{in}$ ), although he claimed to be $2.59-2.62 \mathrm{~m}$. ( $8 \mathrm{ft}$ 6-7 in). He grew up in El Paso, Texas where he also finished high school, and obtained his nicknames: "Pecos Bill", "The Texas Giant", "The El Paso Giant", and "Texas Jack". He worked in the movie business, painted, and sculpted. He was a prize-winning photographer and a poet (he published a book of poetry called: "The Long Shadows").

In 1932 he was examined by Rowe and Mortimer who also recorded some anthropometric data [69]. His height was $228.6 \mathrm{~cm}$ (7 ft 6 in) and he weighed $163.3 \mathrm{~kg}(360 \mathrm{lbs})$. The length of the hands was $254 \mathrm{~mm}$ (10 in) and the length of the feet was $330 \mathrm{~mm}$ ( $1 \mathrm{ft} 1 \mathrm{in})$. Ophthalmology revealed normal visual acuity. The blood sugar level was claimed to be slightly elevated: $6.4 \mathrm{mmol} / \mathrm{l}(117 \mathrm{mg} / \mathrm{dl})$. On the skull radiograph hyperostosis frontalis, together with excessive pneumatisation of the maxillary and frontal sinuses was found. Also, a profound prognathism was recorded. The sellar diameters were: $11 \times 14 \mathrm{~mm}$ and the sellar floor was depressed, which was claimed to be suggestive of an intrasellar tumor. Jack Earle's movie career came to an end after a fall during the filming of one of his movies. He broke his nose and needed hospitalization. During hospital admission, he first lost his temporal eyesight and within the next few 


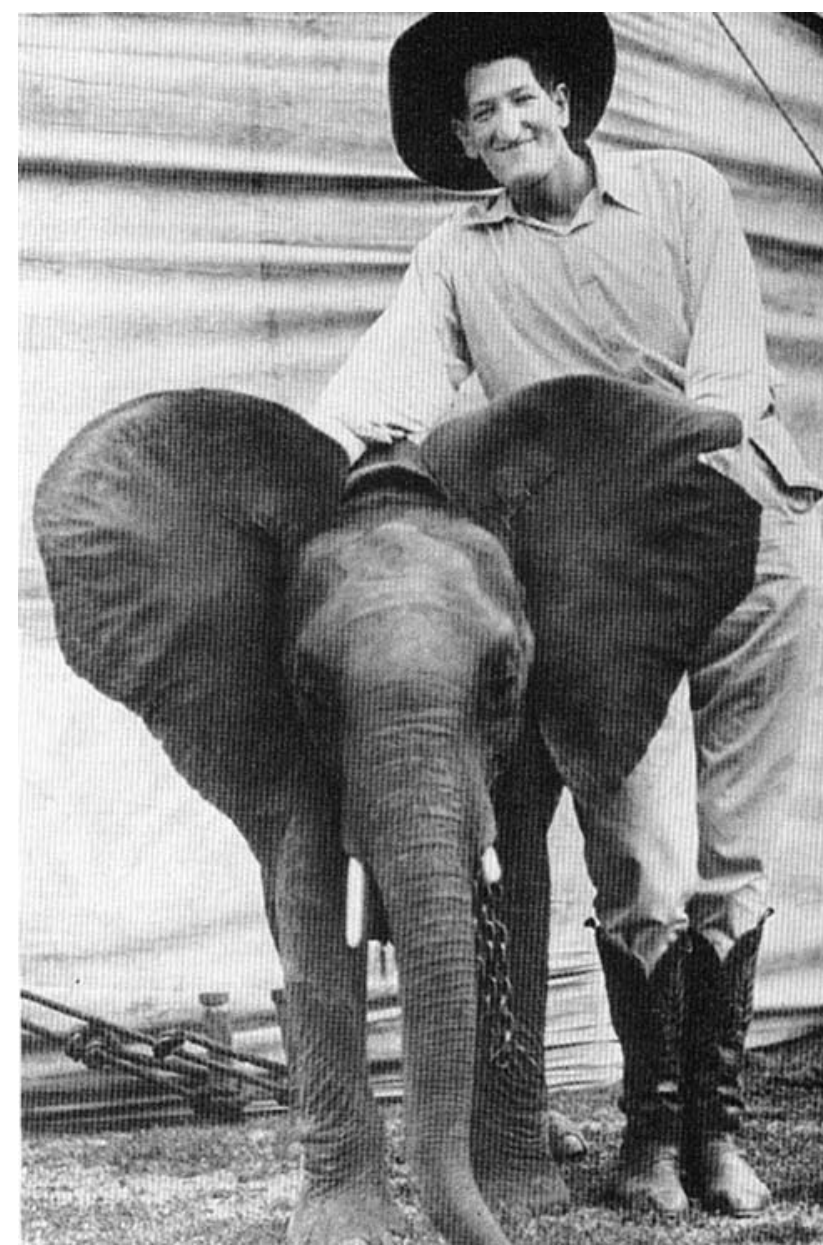

Fig. 7 Jacob Ehrlich (Jack Earle) (1906, Denver (Colorado, USA)— 1952 El Paso (Texas, USA)). Collection W.W. de Herder

days he developed complete blindness. This was presumably caused by a pituitary macroadenoma compressing the optic chiasm and nerves. He was treated with external pituitary radiotherapy, which resulted in the restoration of his visual acuity. It was also claimed that the pituitary radiotherapy may have stopped his further growth. In 1942, Franks reported on a successful esthetic operation to correct severe overbite in Jack Earle [70]. Jack Earle died as a result of a fatal car crash.

Johann Petursson (Jóhann Svarfdælingur-1913, Dalvik (Iceland)—1984, Dalvík (Iceland)) had a normal development till the age of 15 after which accelerated growth occurred (Fig. 8). At the age of 17 he was very strong and could lift a lorry, but at the age of 20 he was weak and suffered from walking difficulties. At the age of 22, he was studied by Krabbe in Copenhagen in 1935, who also recorded his anthropometric data [71]. His height was $2.205 \mathrm{~m}$. (7 ft 23/4 in), his weight was $135 \mathrm{~kg}(298 \mathrm{lbs})$. Krabbe at that stage initially doubted whether Petursson was suffering from acromegalic gigantism, as his body

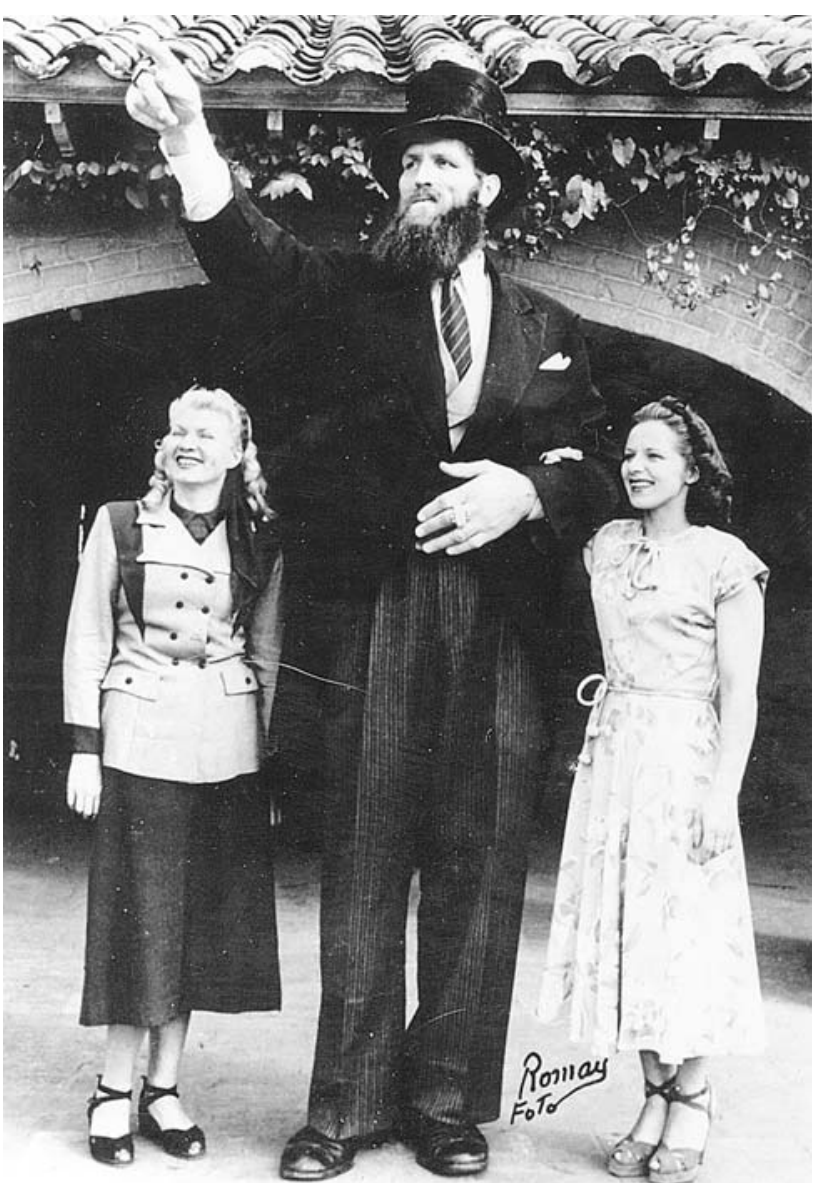

Fig. 8 Johann Petursson (Jóhann Svarfdælingur) (1913, Dalvik (Iceland)—1984, Dalvík (Iceland)). Collection W.W. de Herder

proportions were normal and there were no signs of hypogonadism. However, a sellar radiograph revealed a considerably enlarged sella turcica ( $3 \mathrm{~cm}, 1.2 \mathrm{in})$. He was re-examined in 1939 by Günther in Leipzig and again measured [72-74]. At that time he had a height of $2.225 \mathrm{~m}$ ( $7 \mathrm{ft} 3 \frac{1}{2}$ in). He was featured in films and magazines, and appeared with every major circus and carnival until he retired. His artists names were "Olaf" and "der Nordische Riese Olaf" in Germany and "the Icelandic Giant" or "the Viking giant" in the US. He is buried in Dalvik (Iceland).

What happened in next decades is well-reviewed. Case reports made place for studies into the epidemiology of acromegaly and gigantism. The physiology of the growth hormone-IGF system was slowly unraveled. The pathophysiology of growth disorders was further studied. Assays for growth hormone, its receptors, IGF-I and its binding proteins were developed. MRI became the standard imaging technique for sellar pathologies. Pituitary surgery and pituitary radiotherapeutical techniques and protocols were developed and are continuously being improved. Therapeutic regimens for treating growth hormone excess 
and for replacement of pituitary insufficiencies were and still are being developed, tested and applied in clinical practice [44, 45, 75-89]. Early recognition of developing gigantism at a young age and adequate medical care in the western countries are the main reasons why gigantism has almost completely disappeared in the western world. [90]. But in Africa, South America and Asia gigantism is currently still diagnosed at a late stage.

Open Access This article is distributed under the terms of the Creative Commons Attribution Noncommercial License which permits any noncommercial use, distribution, and reproduction in any medium, provided the original author(s) and source are credited.

\section{References}

1. Marie P (1886) Sur deux cas d'acromégalie; hypertrophie singulière non congénitale des extrémités supérieures, inférieures et céphalique. Rev Med Liege 6:297-333

2. Wier (Weyer) J (1567) Medicarum Observationum. In: Virgo Gygantea ex quartana reddita. Oporinus, Basle, pp 7-10

3. Saucerotte N (1801) Accroissement singulier en grosseur des os d'un homme âgé de 39 ans Observation communiquée à l'Académie de chirurgie. Melanges Chir 2:407-411

4. Pearce JM (2006) Nicolas Saucerotte: acromegaly before Pierre Marie. J Hist Neurosci 15(3):269-275. doi:10.1080/0964704 0500471764

5. Alibert (1822) Précis théorique et pratique des maladies de la peau. Caille \& Ravie: 317

6. Verga A (1864) Caso singolare de prosopectasia. Reale Ist Lombardo Sci Lettere Bendiconti Cl Sci Mat Naturali 1:111-117

7. Lombroso C (1869) Merkwürdiger Fall von allgemeiner Hypertrophie (macrosomia) oder scheinbarer Elephantiasis, beobachtet von Prof. Lombroso, mitgeteilt von Dr. Fränkel. Virchow's Archiv für Pathologische Anatomie Physiologie und für Klinische Medizin Band 6, vierte Folge, p 253

8. Lombroso C (1868) Caso sinolare di macrosomia. Giornale Ital delle Malattie Venere

9. Souza-Leite JD (1890) De l'acromégalie. maladie de Marie, Paris

10. Marie P, Marinesco G (1891) Sur l'anatomie pathologique de l'acromégalie. Archive de médicine expérimentale et d'anatomie pathologique 1re série, tome 3:539-564

11. Marie P (1888) L'acromégalie. Nouv Iconographie Salpetriere I: 173

12. Marie P (1888) L'acromégalie. Nouv Iconographie Salpetriere I:229

13. Marie P (1889) L'acromégalie. Nouv Iconographie Salpetriere II:327

14. Marie P (1889) L'acromégalie. Nouv Iconographie Salpetriere II: 139

15. Marie P (1889) L'acromégalie. Nouv Iconographie Salpetriere II: 188

16. Marie P (1889) L'acromégalie. Nouv Iconographie Salpetriere II:45

17. Marie P (1889) L'acromégalie. Nouv Iconographie Salpetriere II:224

18. Marie P (1890) Acromegaly. Brain 12:59. doi:10.1093/brain/ 12.1-2.59

19. Marie $P$ (1896) Troisième leçon: Déformations thoraciques dans quelques affections médicales (Suite). B. Déformations thoraciques acquises. Acromégalie. Leçons de Clinique Médicale. Masson, Paris
20. Minkowski O (1887) Über einem Fall von Akromegalie. Berliner klinische Wochenschrift 21:371-374

21. Massolongo R (1895) Hyperfonction de la glande pituitaire et acromégalie; gigantisme et acromégalie. Rev Neurol 3:225

22. Tamburini A (1894) Beitrag zur Pathogenese der Akromegalie. Zentralblatt für Nervenheilkunde und Psychiatrie 17(5):625

23. Hutchinson W (1898) The pituitary gland as a factor in acromegaly and giantism. N Y Med J 67:341-344

24. Hutchinson W (1898) The pituitary gland as a factor in acromegaly and giantism. N Y Med J 67:450-453

25. Hutchinson W (1890) The pituitary gland as a factor in acromegaly and giantism. N Y Med J 72:89-100

26. Hutchinson W (1898) The pituitary gland as a factor in acromegaly and giantism. N Y Med J 72:133

27. Benda C (1901) Die microscopischen Befunde bei vier Fällen von Akromegalie. Dtsch Med Wochenschr 27:537-564

28. Guinon G (1889) De l'acromégalie. Gaz Hop Paris 62:1161

29. Fritsche CF, Klebs E (1884) Ein beitrag zur Pathologie des Riesenwuchses. Klinische und pathologischanatomische untersuchungen. Vogel, FCW, Leipzig

30. Langer K (1872) Über Wachstum des menschlichen Skelets, mit Bezug auf den Riesen. Denkschr der Kais Akad der Wissensch zu Wien Math -naturw Kl. p 31

31. Sternberg M (1894) Beiträge zur Kenntnis der Akromegalie. Z Klin Med 27:86

32. Sternberg M (1897) Die Akromegalie. In: Nothnagel CWH (ed) Nothnagel's Encyclopedia. Vienna

33. Cunningham DJ (1891) The skeleton if the Irish giant Cornelius Magrath. Trans R Ir Acad 29:553

34. Cunningham DJ (1903) Cornelius Magrath, the Irish giant. Man (Lond) 3:49-50. doi:10.2307/2840853

35. Cunningham DJ (1892) The skull and some of the other bones of the skeleton of Cornelius Magrath, the Irish giant. J Anthropol Inst Great Br Irel 21:40-41. doi:10.2307/2842207

36. Dana C (1893) On acromegaly and gigantism, with unilateral facial hypertrophy. J Nerv Ment Dis 18:725-738. doi: 10.1097/00005053-189311000-00001

37. Hutchinson W (1895) A case of acromegaly in a giantess. Am J Med Sci CX:190-201

38. Hutchinson W (1898) The pituitary gland as a factor in acromegaly and giantism. NY Med J April 2:450-453

39. Hutchinson W (1898) The pituitary gland as a factor in acromegaly and giantism. NY Med J March 12:341-344

40. Hutchinson W (1900) The pituitary gland as a factor in acromegaly and giantism. NY Med J July 21:89-100

41. Brissaud E, Meige H (1895) Gigantisme et acromégalie. Journal de médicine et de chirurgie pratiques 66:49

42. Launois PE, Roy P (1904) Études biologiques sur les Géants. Masson et Cie, Paris

43. Fulton JF (1946) Harvey cushing. A biography. Springfield, Illinois

44. Cushing H (1930) Neurohypophysial Mechanisms from a Clinical Standpoint. Lancet 2:119-127. doi:10.1016/S01406736(01)09033-X

45. Cushing H (1930) Neurohypophysial mechanisms from a clinical standpoint. Lancet 2:175-184. doi:10.1016/S01406736(01)09081-X

46. Bergland RM (1965) New information concerning the Irish giant. J Neurosurg 23(3):265-269

47. Virchow R (1885) Den Riesen Winkelmeier aus Oberösterreich. Z Ethnol 17:469-472

48. Virchow R (1900) Riese Lewis Wilkins. Z Ethnol 32:78-80

49. de Herder WW (2005) A postcard of a giant and his physician (collection W.W. de Herder). J Endocrinol Invest 28(4):392

50. Lamberg L (1896) Riesenwuchs. Wien Klin Wochenschr 18:359 
51. Bassoe P (1903) Gigantism and Leontasis Ossea, with report of the case of the giant Wilkins. J Nerv Ment Dis 30:513-532. doi: 10.1097/00005053-190309000-00001

52. Bassoe P (1903) Gigantism and Leontasis Ossea, with report of the case of the giant Wilkins. J Nerv Ment Dis 30:595-621. doi: 10.1097/00005053-190310000-00002

53. Mairhofer Irrsee H (2002) Der Riese von Lengau. Verlag Irrsee, Zell am Moos

54. von Luschan F (1903) Der Riese Machnow. Ztschr Ethnologie 35:479-481

55. Zondek M (1904) Beitrag zur Lehre vom Riesenwuchs. Arch Klin Chir 74:890-907

56. Symmers D (1917) Acromegalic Giantism. Interstate Med J 24:1013-1015

57. Orengo N (1992) Figura Gigante. Giulio Einaudi editore s.p.a, Torino, Italy

58. Alexander-Jones C (1998) An introduction to frederick the english giant. Newline Commercial Print limited, Bath

59. Gigon A (1921) Über Zwergwuchs und Riesenwuchs Mit einem Beitrag zum Studium verwandter Entwicklungsstörungen im Organismus. Arch Neurol Psychiat 9:283-303

60. Gigon A (1921) Über Zwergwuchs und Riesenwuchs Mit einem Beitrag zum Studium verwandter Entwicklungsstörungen im Organismus. Arch Neurol Psychiatry 10:113-129

61. Schlaginhaufen O (1958) Bulletin der Schweizerischen Gesellschaft für Anthropologie und Ethnologie, p 35

62. de Herder WW (2004) Reuzengroei. een historische en medische beschouwing. Ned Tijdschr Geneeskd 148(52):2585-2590

63. Humberd CD (1938) Giantism Report of a case. South Med J 31(9):988-992

64. de Herder WW (2005) A bronze statue of the tallest acromegalic giant. J Endocrinol Invest 28(672):672

65. Behrens LH, Barr DP (1932) Hyperpituitarism beginning in infancy. The Alton Giant. Endocrinology 16:120-128

66. Fadner F (1944) The gentleman giant. Bruce Humpries, Inc, Boston

67. Humberd CD (1937) Giantism report of a case. JAMA 13:544546

68. Gray H (1937) The Minneapolis giant. Ann Intern Med 10:1669-1682

69. Rowe AW, Mortimer H (1934) Endocrine studies: XLII. A note on acromegaly with the report of a case. Endocrinology 18:20-32

70. Franks RI (1942) An orthodontic and prosthetic restoration in the mouth of the largest man in the world. Am J Orthod 28:580-583

71. Krabbe KH, Matthiasson S (1936) Géantisme hypophysaire. Acta Med Scand Suppl 78(8):926-932

72. Günther H (1939) Proportionsstudien an Riesen. Endokrinologie 22:81-90

73. Günther H (1939) Proportionsstudien an Riesen. Endokrinologie 22:175-181

74. Günther H (1939) Proportionsstudien an Riesen. Endokrinologie 22:264-270

75. Cushing H (1912) The pituitary body and its disorders. Clinical states produced by disorders of the hypophysis cerebri. JB Lippincott, Philadelphia (Pennsylvania, USA)

76. Davidoff LM (1926) Studies in acromegaly II. Historical note. Endocrinology 10:453-460

77. Davidoff LM (1926) Studies in acromegaly III. The anamnesis and symptomatology on one hundred cases. Endocrinology $10: 461-483$

78. Cushing H, Davidoff LM (1927) Studies in acromegaly IV. The basal metabolism. Arch Intern Med 39:673-697

79. Cushing H, Davidoff LM (1927) Studies in acromegaly V. The pathological finding. in four autopsied cases of acromegaly with a discussion of. their significance. Monograph, Rockefeller Institute for Medical Research, p 22

80. Cushing H, Davidoff LM (1927) Studies in acromegaly VI. The disturbances of carbohydrate metabolism. Arch Intern Med 39:751-779

81. Bailey P, Cushing H (1928) Studies in Acromegaly. VII. The microscopical structure of the adenomas in acromegalic dyspituitarism (Fugitive Acromegaly). Am J Pathol 4(6):545-564

82. Ben Shlomo A, Melmed S (2008) Acromegaly. Endocrinol Metab Clin North Am 37(1):101-122. doi:10.1016/j.ecl. 2007.10.002

83. Melmed S (2006) Medical progress. Acromegaly N Engl J Med 355(24):2558-2573. doi:10.1056/NEJMra062453

84. Melmed S (2008) Update in pituitary disease. J Clin Endocrinol Metab 93(2):331-338. doi:10.1210/jc.2007-1409

85. Guillemin R (2006) Acromegaly, day one and now, 120 years later. Neuroendocrinology 83(3-4):136-138. doi:10.1159/0000 95520

86. Sheaves R (1999) A history of acromegaly. Pituitary 2(1):7-28. doi:10.1023/A:1009913719680

87. Pless J (2005) The history of somatostatin analogs. J Endocrinol Invest 28(11 Suppl International):1-4

88. Lindholm J (2006) Growth hormone: historical notes. Pituitary 9(1):5-10. doi:10.1007/s11102-006-7557-4

89. Lindholm J (2007) A century of pituitary surgery: Schloffer's legacy. Neurosurgery 61(4):865-867

90. Gagel RF, McCutcheon IE (1999) Images in clinical medicine. Pituitary gigantism. N Engl J Med 340(7):524. doi:10.1056/ NEJM199902183400705

91. Gall FJ, Spurzheim JC (1810) Anatomie et physiologie du systeme nerveux en general et du cerveau en particulier. Atlas P1:XLV. Schoëll, Paris

92. Magendie M (1839) Leçons sur les fonctions et les maladies du systéme nerveux. Paris

93. Chalk OF (1857) Trans Pathol Soc Lond 8:305

94. Friedreich N (1868) Hyperostose des gesammten skelettes. Virchows Arch Pathol Anat Physiol Klin Med 43:83

95. Henrot H (1877) Notes de clinique médicale. Des lésions anatomiques et de la nature du myxoedéme, Reims

96. Henrot H (1882) Notes de clinique médicale. Des lésions anatomiques et de la nature du myxoedéme, Reims, pp 112-122

97. Brigidi V (1881) Studii anatomopatologica sopra un uomo divenuto stranamente deforme per chronica infirmita. Arch Scuola Anat Patol Firenze 65-92

98. Brigidi V (1877) Studii anatomopatologica sopra un uomo divenuto stranamente deforme per chronica infirmita. Societe medico-fisica Fiorentina

99. Taruffi C (1877) Scheletro bolognese con prospoectasia e tredici vertebre dorsali. Memorie della Reale Accad delle Sceinze dell'Instituto di Bologna, p 3

100. Taruffi C (1879) Scheletro bolognese con prospoectasia e tredici vertebre dorsali. Ann Universali Med Chir 247:339-388

101. Cunningham DJ (1879) A large sub-arachnoid cyst involving the greater part of the parietal bone of the brain. J Anat Physiol 13:508-517

102. Ellinwood C (1883) Osteitis deformans. San Fran West Lancet $5: 12$

103. Hadden W, Ballance C (1888) A case of acromegaly. BMJ 1(1425):855-856

104. Hadden W, Ballance C (1885) A case of hypertrophy of the subcutaneous tissues of the face, hands and feet. Trans Clin Soc $18: 201-208$

105. Wadsworth OF (1885) A case of myxoedema with atrophy of the optic nerves. Boston Med Surg J 112:5-6 